\title{
On Ignorance: A Vindication of the Standard View
}

\begin{abstract}
Rik Peels has once again forcefully argued that ignorance is not equivalent to the lack or absence of knowledge. In doing so, he endeavors to refute the Standard View of Ignorance according to which they are equivalent, and to advance what he calls the "New View" according to which ignorance is equivalent (merely) to the lack or absence of true belief. I defend the Standard View against his new attempted refutation.
\end{abstract}

Keywords: Ignorance, Belief, Knowledge, Propositions, Facts, Truth

\section{Introduction}

In two important recent articles in this journal, "What is Ignorance?" (Philosophia (2010) 38:5767) and "Ignorance is Lack of True Belief: A Rejoinder to Le Morvan" (Philosophia (2011) 39(2): 344-355), Rik Peels forcefully challenges the Standard View of Ignorance according to which ignorance is the lack or absence of knowledge. He argues for an alternative, the "New View," according to which ignorance is (merely) the lack of true belief. ${ }^{1}$ His second article is a rejoinder to my defense of the Standard View in "On Ignorance: A Reply to Peels" (Philosophia (2011) 39(2):335-344). My aim in the present paper is to defend the Standard View against his new and important challenge.

\footnotetext{
${ }^{1}$ The expression "Standard View" is from Le Morvan (2011) whereas the expression "New View" is the one Peels (2011) uses to describe his own position.
} 


\section{Some Preliminaries}

The central idea of the New View that ignorance is (merely) the lack of true belief may be put more precisely as follows: Someone $S$ is ignorant that $p$ if and only if $S$ does not believe that $p$ when $p$ is true. Let $C$ be: $S$ does not believe that $p$ when $p$ is true. It's very important to notice that the Standard and New Views agree that $C$ is a sufficient condition for $S$ 's being ignorant that $p .^{2}$ Where the Standard and New View differ is on whether $C$ is a necessary condition for $S$ 's being ignorant that $p$. The New View holds that it is, whereas the Standard View holds that it is not. On the Standard View, for instance, $S$ could have the true belief that $p$ and yet still be ignorant that $p$ if $S$ does not meet some other requirement for knowing that $p(e . g$. , if $S$ lacks sufficient justification or warrant to believe that $p$ ). The debate between the Standard and New Views thus concerns not whether $C$ is a sufficient condition for ignorance, but whether it is a necessary one.

The crux of Peels's new case against the Standard View and for the New View consists of two arguments: The Revised Argument and the Excuse Argument. Before proceeding to them, however, Peels attempts to answer (a) my criticisms of his characterization of Dispositional Accounts of Belief and (b) my charge that he conflated propositional and factive ignorance in arguing against the Standard View of Ignorance.

In the present paper, I shall not respond to Peels's attempt to answer (a) for the following reasons. ${ }^{3}$ First, Peels's new case does not turn on whether he is right concerning (a), and considering it here would distract from the crux of his case since a proper examination of it

\footnotetext{
${ }^{2}$ Let me make explicit that this holds insofar as the Standard View maintains that the true belief that $p$ is a necessary condition for $S$ 's knowing that $p$.

${ }^{3}$ Peels (2010) characterized what he calls "Dispositional Accounts of Belief" as holding that (i) "one need not have considered a proposition in order to believe it," and (ii) "for any person $S$ and proposition $p, S$ believes, disbelieves,
} 
would require an excursus into the nature of belief. Second, Peels (p. 347) himself avers that he

is not defending Dispositional Accounts of Belief. Third, it is not clear that anyone in the

literature has ever defended such accounts. ${ }^{4}$ For the purposes of the present paper, then, I shall

assume that Dispositional Accounts of Belief as Peels characterizes them are false, but I shall not

make the case for that here. ${ }^{5}$ In making this assumption, I do not dispute (in fact, I agree with)

or suspends judgment on $p$ (assuming that belief and disbelief are mutually exclusive)" (pp. 58-59). Peels (2011) concedes that (ii) is untenable but thinks that (i) is tenable. He claims that such putative accounts hold that a "mere disposition to believe that $p$ suffices for believing that $p$, so that one need not ever have considered whether $p$ in order to believe that $p$ " (p. 346) and "for all propositions that one is able to grasp, one has some doxastic attitude or other toward it" (p. 347). By “doxastic attitude," he means belief, disbelief, or suspension of judgment.

${ }^{4}$ As examples of philosophers who allegedly hold versions of "Dispositional Accounts of Belief" as he characterizes them, Peels mentions Cohen 1995, Braithwaite 1967, Ramsey 1931, Ryle 1961, and Schwitzgebel 2002. Peels, however, gives no textual evidence that Braithwaite, Ramsey, Ryle, or Schwitzgebel advance a Dispositional Account of Belief as he has characterized it, and I can find no such evidence that they did. While each takes belief to be dispositional in the sense that belief can non-occurrent (a view that is widely accepted and that I do not dispute), this is NOT the same as claiming that someone could believe that $p$ (whether occurrently or nonoccurrently) without ever having considered that $p$. As for Cohen (1995), it's far from clear that he held that someone could believe that $p$ without ever having considered that $p$. Cohen did hold that "if you have believed that Oxford is larger than St Andrews, then you probably (...) have long believed that London is larger than St Andrews, even if your belief has never explicitly occurred to you until you were asked. Indeed, even if you have never consciously believed anything implying that London is larger than St Andrews, your answer to the question 'Do you believe that London is larger than St Andrews?' would most probably be 'Yes'. That is to say, a present feeling that London is larger than St Andrews would be taken to display a pre-existing disposition to feel this" (p. 5). However, to claim as Cohen does that one can non-occurrently believe that $p$ without having occurrently believed that $\mathrm{p}$ is NOT the same as claiming that one can non-occurrently believe that $p$ without having considered that $p$. Peels, it seems to me, misreads Cohen by failing to draw this distinction, and this misreading is worse than I suspected suspected. We must also keep in mind that there is a crucial distinction between a disposition to believe that $p$ and a dispositional belief that $p$. The former unlike the latter is not an actual (though non-occurrent) belief, but rather concerns a belief one would have (whether occurrently or non-occurrently) under certain circumstances; thus, it is possible for one to have dispositions to believe some propositions even if those propositions are not such that one yet believes them (whether occurrently or non-occurrently). A reviewer of this journal has rightly pointed out that Cohen does not (explicitly) say that it is necessary that one have considered a proposition at some earlier time in one's life in order to believe it. However, Cohen does not explicitly deny this either, and in fact the language he uses ("one is attending to issues raised, or items referred to, by the proposition that $p$ ") can be read as implicitly suggesting that the proposition in question has been or is being considered or entertained. In fairness, I should note that in correspondence, Schwitzgebel has indicated to me that although he has not in any of his writings defended the view that one can believe unconsidered propositions, he is inclined to accept this in some cases but not in others. He writes that his view is evolving and one that he wants to reflect further on.

${ }^{5}$ Let me, however, briefly say that I find such putative accounts quite implausible in purporting that someone could believe that $p$ without ever having considered that $p$. Of course, there are plenty of beliefs that one may potentially have with regard to propositions that one has not considered, but this is NOT the same as holding that one actually has such beliefs (whether occurently or non-occurrently). Someone $S$ may indeed potentially believe all kinds of propositions (e.g., that Hillary Clinton is not identical to her autobiography), but unless $S$ has considered a proposition $p$, it seems highly implausible to claim that $S$ actually believes that $p$ whether occurently or nonoccurrently - we must not confuse a disposition to believe that $p$ with a dispositional belief that $p$. This implausible 
the non-controversial thesis that beliefs can be occurrent or dispositional (i.e., non-occurrent); I do, however, hold that one can believe that $p$ (whether dispositionally or occurrently) only if one has considered that $p .^{6}$

As for (b), since Peels has abandoned his previous formulation of his argument against the Standard View, I shall not recapitulate it here; I shall only address the points that he raises in response to my criticisms which are relevant to his new case. In particular, I shall respond to Peels's rejection of the distinction I drew between propositional and factive ignorance, for as we shall see, this distinction proves quite relevant to whether Peels's Revised Argument is sound. I shall then argue that both his Revised Argument and Excuse Argument fail, and in doing so provide reasons for the vindication of the Standard View.

With these preliminary points in mind, let's now consider Peels's new case against the Standard View and for the New View.

\section{Propositional and Factive Ignorance}

In advancing his new case, Peels rejects my distinction between propositional and factive ignorance, and contends that the only kind of ignorance is factive ignorance. ${ }^{7}$ Since the latter

claim, moreover, multiplies actual beliefs without necessity, and thereby runs afoul of Occam's Razor, a principle that applies, contrary to what Peels (2011, p. 348) implies, even if beliefs are non-physical.

${ }^{6}$ While there may be some intuitive pull to the idea that people may believe some propositions (e.g., that Barack Obama has two lungs) that they have never considered before, I think this can be explained away as a case akin to what is known in social psychology as hind-sight bias or the "I knew it all along phenomenon" by which people tend to overestimate with hind-sight how much they actually knew. See Myers 1994, pp. 15-19. This can happen in the case of knowledge, and I think something similar can happen in the case of belief. For instance, when we consider the proposition that Barack Obama has two lungs, this may strike us so obvious that we may be inclined to think that we (and others) believed it all along even if we (and they) had never considered the proposition before. We can, however, account for the explanandum in question in terms of potential beliefs (or dispositions to believe) rather than with actual beliefs (whether occurrent or dispositional).

${ }^{7}$ His position is thus even more radical than I suspected, for Peels's new case makes clear that he is not conflating propositional and factive ignorance, but rejecting propositional ignorance altogether. 
contention underpins his Revised Argument, it's important that we consider his rejection of the distinction. In doing so, I will first amplify on the distinction especially since Peels admits to having "some trouble in understanding the concept of propositional ignorance" (p. 349) and avers that he finds the distinction between propositional and factive ignorance "highly unnatural" (p. 350).

Propositions have truth-conditions, and we can distinguish between their truth-conditions and the satisfaction of those truth-conditions. Propositions are true if their truth-conditions are satisfied, and false if not. Let $p$ be the proposition that Gjertrud Schnakenberg was born in Berlin. I am considering that proposition right now. Whether or not $p$ is true (as it happens, she was born in Tacoma, Washington and not Berlin), my considering or entertaining that $p$ requires that I not be ignorant of $p$ (and its associated truth-conditions), for inasmuch as I am ignorant of $p$, I am in no position to consider or entertain that $p$. In other words, being ignorant of $p$ precludes being able to consider or entertain that $p$. Moreover, inasmuch as one's believing that $p$ requires one's having considered or entertained that $p$, one's believing that $p$ requires that one not be ignorant of $p$. Propositional ignorance is thus, as I put it in Le Morvan 2011, "ignorance of a proposition, and is incompatible with having any belief that expresses that proposition" (that is, with having any belief that has that proposition as its content). (p. 341) Put in terms of truthconditions, propositional ignorance involves ignorance of the truth-conditions associated with a proposition. ${ }^{8}$

\footnotetext{
${ }^{8}$ Whether propositional ignorance is identical to ignorance of a proposition's truth-conditions turns on such issues as whether propositions are identical to their truth-conditions, a view on which my conception of propositional ignorance is neutral (that is, it does not entail it, nor does it preclude it). As a reviewer has pointed out, if one holds that one is propositionally ignorant of some proposition $p$ with truth-conditions $T C$ iff one is ignorant that truthconditions $T C$ are $p$ 's truth-conditions, then propositional ignorance would turn out to be a species of factive
} 
Now, someone who is not ignorant of a proposition (or its truth-conditions) may still be ignorant of a related fact (namely, that those truth-conditions are satisfied). For instance, consider the proposition $q$ that calcium is the element with atomic number 20. My considering $q$ entails that I am not ignorant of $q$, but I may still be ignorant that $q$ 's truth-conditions are satisfied - of the fact that calcium is the element with atomic number 20. Factive ignorance is, as I put it in Le Morvan 2011, "ignorance of a fact" and is distinct from propositional ignorance (p. 341). Put in terms of truth-conditions, factive ignorance involves ignorance that a proposition's truth-conditions are satisfied. One is factively ignorant if one believes false propositions and also if one fails to believe true propositions. ${ }^{9}$

If we think in terms of the widely accepted Correspondence Theory of Truth, we can think of a proposition as being a truth-bearer (which serves as the content of belief and other propositional attitudes and which has a truth-value whether or not one knows it), and a fact as being a truth-maker (a state of affairs denoted by a proposition, which, if it obtains, makes the proposition true). ${ }^{10}$ Propositional ignorance so conceived is ignorance of a truth-bearer, whereas factive ignorance is ignorance of a truth-maker.

Before proceeding further, it's important that we first correct a way in which Peels misunderstands propositional ignorance and hence the above distinction. While he correctly notes that according to me, belief, disbelief, and suspension of judgment entail the absence of propositional ignorance, he misconstrues propositional ignorance as entailing that "to be ignorant

\footnotetext{
ignorance, namely factive ignorance that $T C$ are $p$ 's truth-conditions. In such a case, however, we would still have to draw the distinction between the species and the genus.

${ }^{9}$ As I shall later argue, these are not the only ways in which factive ignorance can occur. If one accepts the Standard View, factive ignorance can also occur if a true belief does not have the warrant or sufficient justification for factive knowledge.

${ }^{10}$ The term 'fact' is ambiguous and sometimes is used in the sense of a truth-maker and sometimes in the sense of a true proposition. I mean it only in the former sense.
} 
of a proposition is not to be ignorant of its truth, although it entails such ignorance if the proposition is true" (p. 349). Nowhere do I say this, and this consequence in no way follows. ${ }^{11}$ If one is ignorant of a proposition, then it follows that one is ignorant of its being true, (or of its truth-conditions being satisfied). This is because if one is ignorant of a proposition's truthconditions, then one will presumably be ignorant that they are satisfied. However, just because one is ignorant of a proposition's being true (of its truth-conditions being satisfied), it does not follow that one is ignorant of the proposition itself (or of its truth-conditions). For example, I can consider a proposition (such as Goldbach's conjecture that every even integer greater than 2 can be expressed as the sum of two primes) while being ignorant of whether it is true, but my considering it implies that I am not ignorant of the proposition itself. There is a crucial difference between being ignorant of a proposition and so being ignorant of its truth-conditions, and being ignorant of a fact in the sense of being ignorant that those truth-conditions are actually satisfied. $^{12}$

\footnotetext{
${ }^{11}$ A reviewer of this journal suggests that Peels may be imputing to me the view that to be ignorant of a proposition is identical to not being ignorant of its truth. But this too would misrepresent my view and the latter nowhere says this.

${ }^{12}$ A reviewer of this journal asked the following interesting question: "Can't I believe on the basis of some person's testimony that a proposition $p$ 's truth-conditions are satisfied without knowing what those truth-conditions are? If so, propositional ignorance does not entail factive ignorance." In response, let's consider an example. Suppose that $p$ is Fermat's last theorem and that I believe that its truth-conditions are satisfied on the basis of an esteemed mathematician's testimony that they are. I do so without my knowing what those truth-conditions are (namely, no three positive integers $a, b$, and $c$ can satisfy the equation $a^{n}+b^{n}=c^{n}$ for any integer value of $n$ greater than 2). This is a case of believing that a proposition's truth-conditions are satisfied whatever they may be. But it does not follow from this that propositional ignorance of $p$ does not entail factive ignorance that $p$. For what I am believing in this case is not $p$ (Fermat's last theorem), but rather another proposition, let's call it ' $q$ ', that $p$ 's truth-conditions are satisfied whatever they may be. There is a difference between my believing a proposition $p$ (which is not possible if one is ignorant of its truth-conditions) and my believing a proposition $q$ that some proposition $p$ is true whatever its truth-conditions may be (which is possible if one is ignorant of $p$ 's truth-conditions).
} 
With this correction noted, let's now consider Peels's grounds for rejecting the distinction between propositional and factive ignorance. He adduces two main grounds for this: (i) that the concept of propositional ignorance seems highly unnatural to him, and (ii) that it is not needed.

(i) Peels avers that the concept of propositional ignorance seems highly unnatural to him. Before today, Peels asserts, he has "never considered the proposition that ducks are smaller than leopards." (p. 350) He then asks: "Is there any natural sense of the word 'ignorance' in which I was ignorant of the content of this proposition? I do not think I was ignorant of the truth of this proposition, but even if I was, is there anything else concerning this proposition, something distinct from the truth of it, that I was ignorant of?" (p. 350) Peels finds it hard to think of any such thing, and that he perfectly understands and has "perfectly understood for many years what the sentence expressing this proposition means and what the concepts involved amount to." (p. 350)

Is the concept of propositional ignorance as unnatural as Peels makes out? He picks as an example a proposition (that ducks are smaller than leopards) that strikes many of us as obvious. In such cases, we may be naturally inclined to take ourselves to not be ignorant of the truthconditions of propositions being satisfied, and hence to not be ignorant of the propositions and their truth-conditions themselves. ${ }^{13}$ Even if we grant this, however, it does not follow that there is no distinction between ignorance of propositions and their truth-conditions on the one hand and ignorance of their being satisfied on the other. Even in the case of the proposition that ducks are smaller than leopards, it is possible for someone to not be ignorant of this proposition and its

\footnotetext{
${ }^{13}$ Peels is presupposing here that he is not ignorant of a proposition he has never considered before, and I contest this presupposition. Even if we had never considered this proposition before, we may be readily inclined, once we consider it, to suppose not only that we believe it but that it is true and that we have never been ignorant that it is true. Once more, this can be explained in terms of what social psychologists call "hind-sight bias" or the "I knew-itall-along phenomenon" by which we tend to overestimate how much we knew all along and so were not ignorant of.
} 
truth-conditions while still being ignorant of whether those truth-conditions are satisfied. ${ }^{14}$ And in the case of propositions that may not strike us as obvious at all (e.g., Goldbach's conjecture), it's especially clear that someone who is not propositionally ignorant may still be factively ignorant. ${ }^{15}$ In fact, contra Peels, it seems unnatural to not distinguish between ignorance of a proposition and its truth-conditions (i.e., propositional ignorance) and ignorance of their being satisfied (i.e., factive ignorance).

(ii) Peels contends that the concept of propositional ignorance is not needed. He distinguishes between ignorance simpliciter and ignorance of a proposition $p$ which he takes to be equivalent to ignorance of $p$ 's truth, and claims that "someone who falsely believes that $p$ is not ignorant of $p$ and by that I mean of $p$ 's truth" (p. 350). It seems moreover to Peels that "when philosophers say that $S$ knows, believes, doubts, or is ignorant that $p$, they always mean that $S$ knows, believes, doubts, or is ignorant that $p$ is true" (p. 350) Peels adds:

'Now, being ignorant simpliciter and being ignorant of $p$ ( $p$ 's truth) are two different things. Clearly, someone who falsely believes that he was robbed by a Canadian is ignorant of something, namely that he was not robbed by a Canadian. But equally clearly, that person will not be ignorant that he was robbed by a Canadian, because he was not. (p. 350)

\footnotetext{
${ }^{14}$ For instance, a friend of mine, when asked about the proposition, understood it, but wasn't sure whether its truthconditions were satisfied - she said that it would depend on what kind of ducks and leopards were involved.

${ }^{15}$ Peels adds that even "if Le Morvan were to say that one is propositionally ignorant of $p$ if one cannot grasp $p$, the use of the term 'ignorant' seems unnatural to me. If a person cannot grasp $p$, we would not describe that fact by saying that that person is ignorant of $p$-it seems that if we were to say that, we would mean that that person is ignorant of $p$ 's truth. We would rather say that that person is ignorant of the things or concepts involved, that is, of what those things and concepts amount to" (p. 350) Peels's assertions here are once again unpersuasive, and seem to be based on a failure to distinguish truth-conditions themselves from their satisfaction. If someone cannot grasp $p$, why can we not describe her as being both ignorant of $p$ 's truth-conditions AND ignorant that these are satisfied?
} 
Peels adduces another example to illustrate his point:

Suppose that Billy spreads all kinds of falsehoods, such as lies and rumors, about Jane. For one thing, he falsely claims that Jane has no friends at all. Jane, however, has no idea that Billy does so. Would we not say that Jane is blissfully ignorant of these falsehoods? I think we would (or, at least, we might), but, again, we will have to specify what precisely Jane is ignorant of. It seems that she is ignorant of the fact (the truth) that Billy spreads these rumors and lies about her. But she is not ignorant of the falsehoods themselves. For instance, if she knows that she has many friends, then she is not ignorant that she has no friends at all (remember, this was one of the rumors spread by Billy). As long as we specify which truth we have in mind - which may be a truth that something was not the case - we can explain all ignorance in terms of factive ignorance. (pp. 350-351)

Peels concludes that "we do not need the concept of propositional ignorance as distinct from factive ignorance in order to make sense of cases in which someone believes a false proposition" and that his claim "that one can only be ignorant of truth is undefeated" (p. 351).

Peels's case is problematic on four counts:

First, consider his claim "that someone who falsely believes that $p$ is not ignorant of $p$ and by that I mean of $p$ 's truth." If someone $S$ falsely believes that $p$ (that is, believes that $p$ and $p$ is false), then it follows that $S$ does not believe that $p$ when $p$ is true. This may be seen more formally as follows where " $S$ does not believe that $p$ when $p$ is true" is understood as logically equivalent to " $p \rightarrow \sim(S$ believes that $p)$ ": 
1. $(S$ believes that $p) \& \sim p$. (assumption)

2. $\sim p .(1$, simplification $)$

3. $\sim p \vee \sim(S$ believes that $p)$. (2, addition)

4. $p \rightarrow \sim(\mathrm{S}$ believes that $p)$. (3, logical equivalence $)$

Since on Peels's New View, someone who does not believe that $p$ when $p$ is true is ignorant that $p$ (is true), it follows (given the proof above) that someone who falsely believes that $p$ is ignorant that $p$ (is true). Consequently, his claim "that someone who falsely believes that $p$ is not ignorant of $p$ and by that I mean of $p$ 's truth" contradicts the very New View he is endeavoring to defend if what he means by 'is not ignorant of $p$ and by that I mean of $p$ 's truth' is 'is not ignorant that $p$ (is true),' for in this case, Peels holds that $S$ is not ignorant that $p$ (is true) while the New View he is endeavoring to defend entails that $S$ is ignorant that $p$ (is true). ${ }^{16}$ He could avoid this contradiction by distinguishing propositional ignorance from factive ignorance and by holding that someone who falsely believes that $p$ is not propositionally ignorant of $p$ even if factively ignorant that $p$, but doing so would undermine his claim that the concept of propositional ignorance is not needed.

Second, recall Peels's claim that it seems to him that that "when philosophers say that $S$ knows, believes, doubts, or is ignorant that $p$, they always mean that $S$ knows, believes, doubts, or is ignorant that $p$ is true." When 'know,' 'believe,' 'doubt' and 'ignorant' are followed by

\footnotetext{
${ }^{16}$ It's not clear moreover what else Peels could mean by 'is not ignorant of $p$ and by that I mean of $p$ 's truth'. If he means 'is not ignorant of $p$ 's truth-value', then his view is highly implausible, for why would someone's having a false belief that $p$ mean that he or she is not ignorant of $p$ 's truth-value? Someone who has the false belief that $p$ believes it has a truth-value which is the opposite of the truth-value it actually has, and so is presumably ignorant of its actual truth-value.
} 
'that $p$,' they are typically used with regard to $p$ 's truth. It doesn't follow from this, however, that there are never any readings where 'ignorant' (or 'know') is used with regard to the proposition itself and not its truth. As I have argued, one can be ignorant of a proposition in a sense distinct from being ignorant that it is true. Wouldn't philosophers who consider the matter want to distinguish between ignorance of a proposition and its truth-conditions (as happens with propositional ignorance) and ignorance of the satisfaction of those truth-conditions (as happens with factive ignorance)?

Third, Peels is right that "that someone who falsely believes that he was robbed by a Canadian is ignorant of something, namely that he was not robbed by a Canadian." Why is this so? Let this someone be $S$, let $p$ be the proposition that $S$ was robbed by a Canadian, and let $q$ be the proposition that $S$ was not robbed by a Canadian. Obviously, $p$ and $q$ are contradictories. If one falsely believes that $p$, then one presumably does not believe that $q$, and since $q$ is true, one's failure to believe that $q$ entails that one is (factively) ignorant that $q$. Peels, however, is wrong that "that person will not be ignorant that he was robbed by a Canadian, because he was not." If $S$ believes that $p$ and $p$ is false, $S$ is ignorant that $p$ 's truth-conditions are satisfied (because they are not) and so $S$ is (factively) ignorant that $p$. In fact, as we saw above, Peels's own New View entails that someone who has a false belief that $p$ is (factively) ignorant that $p .{ }^{17}$

Fourth, Peels's attempt to explain away ignorance of falsehoods such as lies and rumors is quite implausible and unnatural. Yes, Sally is ignorant of the fact that Billy is spreading lies

\footnotetext{
${ }^{17}$ It may seem puzzling at first to think that if $S$ has a false belief that $p$, then $S$ is both factively ignorant that $p$ and factively ignorant that $q$ where $p$ and $q$ are contradictories. The puzzle disappears, however, when we consider that factive ignorance arises differently in both cases: in the former, it arises because of a belief in a false proposition, in the latter because of a failure to believe a true proposition. Consider a parallel case with factive knowledge. If I have the false belief that $p$, I presumably do not believe that $q$ (its contradictory). Since I believe the false proposition $p$, I do not know that $p$, but since I do not believe that $q$ either, I do not know that $q$. Hence, if I believe a false proposition $p$, then I neither know that $p$ nor know that $q$ where $p$ and $q$ are contradictories.
} 
and rumors about her, but isn't she also ignorant of those lies and rumors themselves? Peels's claim that we are not (in fact cannot be) ignorant of falsehoods but only of truths fails to make sense of the common notion that one can be ignorant of falsehoods. Such ignorance cannot be explained away as ignorance of truths. Consider this example: suppose Ulrike Schmidt lived in the former East Germany where the Stasi maintained a lengthy and detailed file on her activities and proclivities. Suppose moreover that this file contained all kinds of falsehoods about her. Does it not make eminent sense to suppose that she could have been ignorant of these falsehoods and that her ignorance was later dispelled only after she gained access to her file? That she knew beforehand various truths about herself (truths that were in effect the contradictories of those falsehoods of which she was unaware) does not establish that she was not ignorant of those falsehoods themselves.

On the basis of the above considerations, I conclude that Peels has failed to show that the concept of propositional ignorance is "highly unnatural" and "not necessary" and that my distinction between propositional and factive ignorance stands vindicated. As we shall see, Peels's failure to refute the distinction turns out to be quite relevant to the soundness of his case against the Standard View and for the New View. This will become clear as we next consider his Revised Argument.

\section{The Revised Argument}

In response to my criticisms of his previous argument in Peels (2010), Peels advances a revised argument against the Standard View and for the New View. His argument comes in three key steps. We will critically examine each in turn. 
In the first step of his argument, Peels contends that cases of true belief that are close to but fall just short of being knowledge are not plausible candidates of ignorance (by this he claims to mean only factive ignorance). He gives us what he calls case A where he asks us to imagine the following: "I enter my living room and look at the clock. The clock tells me that it is 3 p.m., so that I acquire the belief that it is $3 \mathrm{p} . \mathrm{m}$. I know that the clock has always worked fine, but I have no idea that the clock stopped working 24 hours ago" (p. 352). Peels then asks us whether we would say that in this Gettier-type case he is ignorant that it is 3 p.m. Peels claims that it seems implausible to say that he is (p. 352).

While this seems implausible to Peels, is it to rest of us? In his imagined case, Peels has a belief that just happens to be true by sheer luck or accident and one based on the false belief that his clock is presently indicating the correct time. On the Standard View, Peels is ignorant in this case of the fact that it is 3 despite his having this true belief. Now, of course, in having the belief that it is 3 p.m., Peels is not ignorant of something. But what that something is can be explained on the Standard View as the proposition that it is 3 p.m. (else he could not presumably have the belief that it is 3 p.m.), and this is a different matter from his not being ignorant of the fact that it is 3 p.m. (where not being ignorant of this fact amounts to not being ignorant that the state of affairs of it being 3 p.m. obtains). I strongly suspect that Peels's intuition here is based on his supposition that the only kind of ignorance is factive ignorance. In any case, I leave it to readers to judge whether their intuitions lie with what the New View or Standard View entails.

In the second key step of his argument, Peels contends that even cases of mere true belief do not seem to count as cases of ignorance. Consider what he calls case B: 
Jim, a truck driver from Miami, believes contrary to all the evidence that he is going to be the next president of the United States. He thus comes to believe that the next president of the United States currently lives in Miami (let us call this proposition $r$ ). As it turns out, the next president is a female congress member living in Miami whom Jim has never heard of. In this case Jim truly believes, but does not know that $r$. Is he ignorant of $r$ ? It seems to me that he is not. (p. 352)

Peels adds that "there are all sorts of truths in the neighborhood of which he is ignorant" and "it is hard mentally to isolate $r$ from all those others propositions, propositions such as Mss. [sic] Jones is going to be the next president, Mss. [sic] Jones lives in Miami, and The next president is currently a congress member" (p. 352). Peels avers that while "we may be inclined to think that Jim is ignorant of $p$ [sic - Peels means $r$ ] because we know that he is ignorant of all these other propositions," if "we focus on $r$, however, it seems that Jim is not ignorant of $r$ " (p. 352).

What are we to make of this line of reasoning? Well, even if we accept that Peels is right that Jim is presumably not ignorant of proposition $r$ (a proposition that happens to be true, namely that the next President of the United States lives in Miami), it doesn't follow that we also have to accept that Jim is not ignorant in another way, i.e. that Jim is not ignorant of the fact that the next President of United States lives in Miami (that the state of affairs that the next President of the United States lives in Miami obtains). Once again, Peels's intuition seems to result from thinking of ignorance only in terms of factive ignorance, and I ask readers to judge whether their intuitions lie with the New View or the Standard View. 
In the third step of his argument, Peels contends that "if both cases of true belief that just fall short of knowledge and cases of mere true belief do not count as cases of ignorance," then "it seems plausible that in between cases do not count as cases of ignorance either" (p. 352).That is because, according the Peels, "the constituents of cases that are closer to knowledge than mere true belief but not as close to knowledge as Gettier-type cases entail true belief and are entailed by a Gettier-type belief," and it "is hard to think of any distinct feature of such cases which would set them apart as cases of ignorance" (p. 352). Howbeit, we have seen above contra Peels that there are reasons to think that even if cases of true belief that just fall short of knowledge and cases of mere true belief do not count as cases of propositional ignorance, they can still count as cases of factive ignorance.

In any case, on the basis of the three key steps discussed above, Peels advances the following argument (p. 352):

P1': In A-type scenarios, $S$ truly believes that $p$, but just falls short of knowing that $p$. [def.]

P2': In A-type scenarios, $S$ is not ignorant of $p$. [ass.]

P3: In B-type scenarios, $S$ merely truly believes that $p$ [def.].

P4: B-type scenarios, $S$ is not ignorant of $p$. [ass.]

P5: If in both A-type and B-type scenarios, $S$ is not ignorant of $p$, then it is plausible to assume that in all in-between cases - cases in which $S$ truly believes that $p$ without merely truly believing that $p$ and without just falling short of knowing that $p-S$ also fails to be ignorant of $p$. [ass.] 
P6: In all cases in which $S$ truly believes that $p$ without knowing that $p, S$ is not ignorant as to whether $p$. [from $\mathrm{P} 2{ }^{\prime}, \mathrm{P} 4$, and $\mathrm{P} 5$ ]

P7: If $S$ believes or suspends judgment on a false proposition $p$ or if $S$ fails to believe a true proposition $p$, then $S$ is ignorant as to whether $p$. [ass.] $\mathrm{C}^{\prime}$ : Ignorance is lack of true belief. [from P6 and P7]

Notice that this argument obviously begs the question against the Standard View by taking A-type and B-type scenarios to not be cases of ignorance. It thus gives us no independent reason for accepting the New View and for rejecting the Standard View. Peels does attempt to parry this charge of question-begging as follows:

The adherent of the Standard View could indeed simply insist that in B-type scenarios or even in A-type scenarios the cognitive subject in question is ignorant of the relevant proposition. If she not only wants to criticize the New View, but also save the Traditional View, she would in fact have to insist that in both A-type and B-type scenarios the subject is ignorant of the relevant proposition. I have attempted to anticipate this line of response by asking the adherent of the Standard View to consider whether she might conflate ignorance of the relevant proposition with ignorance of propositions that are closely related to it. But if, which I hope not, the adherent of the Standard View, after having considered this response, continues to insist as she did before, then I think we have hit rock bottom: our linguistic intuitions simply divert $[$ sic $]$ here. (p. 353) 
His attempt to parry this charge is unsuccessful. First, it is false that if an adherent of the Standard View "not only wants to criticize the New View, but also save the Traditional View, she would in fact have to insist that in both A-type and B-type scenarios the subject is ignorant of the relevant proposition." This is false because the adherent of the Standard View can in fact insist that both A-type and B-type scenarios are not cases of ignorance of the relevant proposition, but of the relevant fact (= a state of affairs obtaining, of a proposition's truthconditions being satisfied). She can insist that while $S$ 's believing that $p$ entails that $S$ is not ignorant of the proposition $p$, it does not entail that $S$ is not ignorant that $p$ is true. Not being ignorant of a proposition that happens to be true is not equivalent to not being ignorant that it is true. It is not the adherent of the Standard View who needs to ask "whether she conflates ignorance of the relevant proposition with ignorance of propositions that are closely related to it," but rather Peels who needs to ask whether he should distinguish ignorance of propositions from ignorance of facts. There may very well be, as Peels suggests, a divergence of intuitions between him and adherents of the Standard View; but his Revised argument fails to give the latter any good reason to convert to the New View and fails to give those not yet committed to either view any independent reason to accept the New View over the Standard View.

Something that Peels's Revised Argument does accomplish is to bring to light a consequential difference between the Standard and New Views. For unlike the Standard View, if we accept the New View, we must accept the consequence that no case of true belief that $p$ counts as (factive) ignorance that $p$ however accidentally or luckily true that belief may be. Accepting the New View thus requires rejecting the intuition that true beliefs that are accidentally or luckily true can be cases of (factive) ignorance. 


\section{The Excuse Argument}

In an attempt to press his refutation further, Peels advances another consideration in support of the New View. He notes that "ever since Aristotle it has been widely acknowledged that ignorance, as long as it is blameless, provides at least a partial excuse" (p. 353). Peels thinks that the New View can make good sense of this, but the Standard View cannot. He asks us to imagine that as the director of a demolition company, he decides to destroy an old barn, one which turns out to be a historical monument. He contends that he is not blameworthy for destroying the old barn if he falsely but blamelessly disbelieves that it is a historical monument or if he has blamelessly not considered and so not believed that it is a historical monument. Peels also contends that if he suspends judgment on whether it is a historical monument, but nevertheless destroys the barn on the basis of the belief that it is unlikely to be a historical monument, then he is blameworthy for destroying the barn, but not as blameworthy as he would have been had he believed that it was a historical monument. (p. 353) In the latter case, "ignorance provides a partial, although not a full excuse" (p. 353). Peels adds: "Since on the New View, every case of ignorance of a proposition $p$ is a case in which one disbelieves that $p$, or in which one suspends judgment on $p$, or in which one has not even considered whether $p$ and does not believe that $p$, the New View can make good sense of the fact that ignorance provides at least a partial excuse" (p. 353).

By contrast, Peels notes (correctly) that on the Standard View there is also another kind of ignorance whereby someone can have the true belief that $p$ without knowing that $p$. Peels objects that "it seems that true belief that fails to be knowledge does not count as an excuse, not even as a partial excuse" (p. 354). He adds: 
Whether I know or merely truly believe that the old barn is an historical monument does not seem to make a difference to the degree of my blameworthiness. In both cases I am blameworthy to an equally high degree (unless other excuses hold). The Standard View, therefore, entails, contrary to what is widely accepted, that not all kinds of blameless ignorance provide at least a partial excuse. I do not say that the fact that one has this true belief renders one blameworthy to the highest degree possible. It may very well be that someone who also intends to do wrong for wrong's sake is even more blameworthy. If so, however, it will be the absence of such an evil intention rather than the presence of one's belief that partially excuses someone with this kind of true belief. (p.

Does this argument refute the Standard View? In a word: No. First of all, let's remember that Standard and New Views are in agreement that $C$ (namely, $S$ does not believe that $p$ where $p$ is true) is a sufficient condition for ignorance. Where they differ is on whether $C$ is a necessary condition for ignorance. As Peels himself acknowledges, if $S$ disbelieves that $p$, does not consider that $p$, or suspends judgment that $p$, in each case, $S$ does not believe that $p$. What we should also acknowledge is that, if $p$ is true in these cases, $S$ 's not believing that $p$ counts as ignorance on both the Standard and New Views, for on both views $S$ 's not believing that $p$ is a sufficient condition for $S$ 's being ignorant that $p$. Accordingly, if $S$ is blameless for not believing that $p, S$ is blamelessly ignorant that $p$ on both the New and Standard Views. 
Second, there is a crucial difference between (i) all cases of blameless ignorance provide at least a partial excuse, and (ii) all cases of ignorance are blameless and provide at least a partial excuse. Peels appears to conflate (i) and (ii) in rejecting the Standard View which entails all the cases of blameless ignorance noted by Peels that the New View does. Even if the Standard View also entails that there are some cases of ignorance that are not blameless (e.g., cases where true belief falls short of knowledge), it does not follow from this that it is incompatible with (i). Just because all cases of blameless ignorance provide at least a partial excuse, it does not follow that all cases of ignorance are blameless and provide at least a partial excuse. Thus, contra to what Peels charges, the Standard View does not entail "contrary to what is widely accepted, that not all kinds of blameless ignorance provide at least a partial excuse"; what it entails is that not all kinds of ignorance are blameless. For instance, in Peels's example of his having the true belief (which falls short of knowledge) that $p$ (= that an old barn is a historical monument), the New View entails that he is not ignorant that $p$ while the Standard View entails that he is ignorant that $p$ (assuming he lacks the justification required for knowledge). If he goes ahead and destroys the barn, he is not blamelessly ignorant on the New View because he is not ignorant in virtue of having a true belief, and he is not blamelessly ignorant on the Standard View because he is presumably not blameless though ignorant. But so what? It's a non-sequitur to think that this somehow shows that the Standard View entails that "contrary to what is widely accepted, that not all kinds of blameless ignorance provide at least a partial excuse.” Peels traduces (I trust unintentionally) the Standard View in rejecting it, and his Excuse Argument proves to be unsound. 
Third, consider the notion of blameworthy ignorance where we hold someone blameworthy for not having known something that they ought to have known. For instance, suppose a father who is engrossed for hours watching a football game on television believes, only as a result of wishful thinking, that his toddler daughter is playing somewhere safe. Suppose that, as a result of sheer luck, she is playing somewhere safe. This is because a kind neighbor who happens to see the child unattended in the yard watches over her to make sure she is okay. The father's belief is thus true, but accidentally so. Isn't this father blameworthily ignorant that his daughter is safe despite his true belief? Should he have not known that his daughter is playing somewhere safe? Despite his true belief, it seems highly plausible to suppose that the father is not only ignorant, but in a blameworthy manner, for he should have known that his daughter is playing somewhere safe. The Standard View can accommodate how true beliefs can count as cases of blameworthy ignorance, but the New View cannot for on the latter no such cases count as ignorance. $^{18}$

\section{Conclusion}

Though Peels has forcefully argued against the Standard View and for the New View, his case proves unsuccessful and he neither refutes the former nor establishes the latter. In fact, on the basis of what I have argued above, we have reason to prefer the Standard View over Peels's New View (at least in the way he has argued for it) if we accept some or all of the following:

(1) there is a distinction between propositional ignorance and factive ignorance;

(2) lack of true belief is sufficient but is not necessary for ignorance;

\footnotetext{
${ }^{18}$ To be sure, an adherent of the New View could hold the father blameworthy of negligence, but my point is that the New View cannot accommodate the notion of true beliefs counting as instances of blameworthy ignorance.
} 
(3) some cases of true belief are cases of ignorance;

(4) there can be ignorance of falsehoods;

(5) even if some cases of ignorance provide at least a partial excuse, not all cases of ignorance do so;

(6) there can be true beliefs that count as instances of blameful ignorance.

And since we have reason to accept (1)-(6), the Standard View stands vindicated.

\section{References}

Braithwaite, R. B. (1967). The nature of believing. In A. Philips Griffiths (Ed.), Knowledge and belief (pp. 28-40). Oxford: Oxford University Press.

Cohen, L. J. (1995). An essay on belief and acceptance. Oxford: Clarendon.

Le Morvan, Pierre. (2011). “On ignorance: A reply to Peels,” Philosophia, 39(2), 335-344.

---. (2010). Knowledge, ignorance, and true belief. Theoria, 76, 309-318.

Myers, D. (1994). Exploring social psychology. New York: McGraw-Hill.

Peels, R. (2011). “Ignorance is Lack of True Belief: A Rejoinder to Le Morvan” Philosophia, 39(2): 344-355.

---. (2010). What is ignorance? Philosophia, 38, 57-67.

Ramsey, Frank P. (1931). In Richard B. Braithwaite \& George E. Moore (Eds.), The foundations of mathematics. London: Routledge and Kegan Paul.

Ryle, Gilbert. (1969). The concept of mind (Hutchinson \& Co).

Schwitzgebel, E. (2002). A phenomenal, dispositional account of belief. Noûs, 36(2), 249-275. 